\title{
EXPLOSIVE TO EFFUSIVE TRANSITION IN INTERMEDIATE VOLCANISM: AN ANALYSIS OF CHANGING MAGMA SYSTEM CONDITIONS IN DOMINICA
}

JESSICA BERSSON, Whitman College

Research Advisor: Kirsten Nicolaysen, Whitman College

\section{INTRODUCTION}

The oscillation between explosive and effusive intermediate (58-65 wt $\% \mathrm{SiO}_{2}$ ) volcanism at Wotten Waven Caldera on Dominica, an island in the Lesser Antilles Arc, provides an opportunity to investigate temporal changes in the magmatic system. In order to determine possible explanations for the shifting eruptive style a detailed petrologic analysis of phenocrysts is conducted to determine commonalities or changes in pre-eruptive conditions (i.e., intensive variables) for the Roseau Ignimbrite Group ( 1-65 ka) (i.e., the explosive end-member) and the Micotrin Lava Dome ( 1.1-26 ka) (i.e., the effusive endmember), from the Wotten Waven magma system (Frey, 2016; Howe et al., 2014; Lindsay et al., 2005). Samples from the Micotrin Lava Dome and from multiple units of the Roseau Ignimbrite were collected and analyzed for major element chemistry, trace element chemistry, and mineral geochemistry. Oxide geothermometry (Ghiorso and Evans, 2008) demonstrates pre-eruptive magma temperatures and oxygen fugacity $\left(\mathrm{fO}_{2}\right)$. Plagioclase hygrometry (Waters and Lange, 2015) reveals melt water content at the time of peak crystallization of plagioclase. These variables define pressure conditions of the magma storage at the time of the eruptions of the Roseau Ignimbrite and the effusion of the Micotrin Lava Dome. This study aims to better define the magmatic evolution of the source and the shift in volcanism from explosive to effusive by integrating a petrological analysis with past and ongoing geochronological research. Here we see a disparity in $\mathrm{SiO}_{2}$ content, pre-eruptive temperatures, melt water content, and pressure between the ignimbrite and dome deposits suggesting a complex evolution of the magma system beneath Micotrin. Understanding the progression of this complex magma system informs the volcanic hazards Dominica is exposed to, as the capital Roseau (pop. 15,000) sits atop the thick Roseau Ignimbrite Sequence down valley of the Micotrin Lava Dome.

\section{AREA OF STUDY}

\section{Tectonics of Dominica \& the Lesser Antilles Arc}

The Island of Dominica is located centrally on the Lesser Antilles island arc, at the eastern boundary of the Caribbean Sea. The Lesser Antilles island arc, active since the Eocene, is the surface expression of the westward subduction of the North American Plate beneath the Caribbean plate (Lindsay et al., 2005). Dominica is dominated by intermediate pyroclastic deposits and lava domes sourced from nine volcanic centers trending north-south, forming the island's distinct spine. High precipitation rates promote a densely vegetated, rugged landscape with high relief, largely limiting outcrop access to ocean cliffs, valley walls, and quarries. Volcaniclastic fans at the mouth of major valley drainages represent the scarce flat topography on Dominica, and the location of the island's main population centers. Dominica exhibits signs of volcanic unrest, hydrothermal activity, and seismic swarms, which warrant further research into the islands' magma systems to inform potential volcanic hazards, especially given its history of irregular explosive eruptions. 


\section{Wotten Waven Caldera}

The extensive Roseau Ignimbrite Sequence $(\sim 1-65$ ka) and subsequent Micotrin Lava Dome ( 1.1 - 26 ka) have been attributed to the Wotten Waven Caldera, located in central southern Dominica, based on proximity (Lindsay et al., 2005; Smith et al., 2013; Boudon et al., 2017). The caldera is elongate south to southwest extending $7 \mathrm{~km}$ by $4.5 \mathrm{~km}$ with partially fault controlled margins and a subsidence volume between 5 and $7.7 \mathrm{~km}^{3}$ (Smith et al., 2013). The Roseau Ignimbrite Sequence is composed of multiple units representing pulses of explosive activity and subsequent caldera collapse. The Micotrin Lava Dome Complex extruded within the Wotten Waven Caldera following caldera collapse, analogous to, but at a larger scale than, the resurgent lava dome extruded at Mt. St. Helens between 2004 and 2008. Wotten Waven deposits are andesitic to dacitic in composition (58-65 wt\% $\mathrm{SiO}_{2}$ ). The shift from explosive, ignimbrite-forming eruptions to effusive dome-forming activity resembles the classic caldera cycle of Smith and Bailey (1968), defined by oscillations of plinian and peléan style volcanism. Smith et al. (2013) suggest the characteristic alternations may represent volcanic responses to specific conditions (i.e. temperature, water content) within the magma reservoir.

\section{Roseau Ignimbrite and Micotrin Lava Dome Complex}

Plinian eruptive activity produced the Wotten Waven caldera and associated Roseau pyroclastic deposits. The Roseau Ignimbrite Sequence is composed of three distinct stratigraphic units representing multiple eruptive periods, exposed within the caldera and throughout the Roseau Valley (Demange et al., 1985; Smith et al., 2013). Unit 1 is a thick, relatively uniform welded ignimbrite interpreted as deposited from a singular collapse of a plinian eruption column (Smith et al., 2013). Unit 2 is unwelded and contains a paleosol present at Kings Hill, representing a period of inactivity and suggesting at least two distinct eruptive events are represented. Unit 3 is unique in that it contains both unwelded pyroclastic deposits and intermittent block-and-ash flow deposits (Smith et al., 2013). The block-and-ash flows tend to overlie pyroclastic deposits suggesting dome extrusion marks the end of the main eruptive series and represents the transition from plinian to peléan activity (Smith et al., 2013). These block-and-ash flow deposits represent the extrusion, over steepening, and collapse of a lava dome and have been attributed to the Micotrin Lava Dome Complex, two coalesced domes located on the northeastern margin of the Wotten Waven Caldera (Demange et al., 1985).

\section{METHODS}

Roseau Ignimbrite and Micotrin Dome samples were collected over multiple field seasons $(2015,2016$, and 2017) led by Holli Frey. Samples were powdered and analyzed for major and trace elements using ICP-OES at Acme Labs and ICP-MS at Union College. Samples were prepared as thin sections for microbeam analyses. Compositions of magnetite, ilmenite and plagioclase were collected using energy dispersive spectrometry (EDS) with the Zeiss EVO-MA15 Scanning Electron Microscope (SEM) at Union College. The EDS analyses were conducted following a calibration method, where the initial beam intensity is obtained by collecting the energy emitted by a copper plate, then EDS spectra are collected for natural mineral standards in the Union College collection (e.g., grossular, ilmenite, magnetite, anorthite). Compositions of magnetite, ilmenite and plagioclase were also collected using the Cameca SX-100 electron microprobe (EPMA) at University of California Davis. For EPMA analyses, a beam intensity of $15 \mathrm{KeV}$ was used along with an intensity of $20 \mu \mathrm{m}$ and $10 \mu \mathrm{m}$ for oxides and plagioclase, respectively. Oxide analyses were repeated on samples that were analyzed at Union College to test the robustness of the EDS calibration method.

\section{RESULTS}

\section{Petrography}

Both deposits are saturated in five phenocrysts (plagioclase + orthopyroxene + clinopyroxene + ilmenite + magnetite $+/$ - amphibole $+/$ - quartz) but with notable differences: lava dome deposits contain more quartz and relict amphiboles. Ignimbrite deposits are glass-rich, whereas the Micotrin Dome deposits contain little glass with microcrystalline matrices (Fig. 1). 


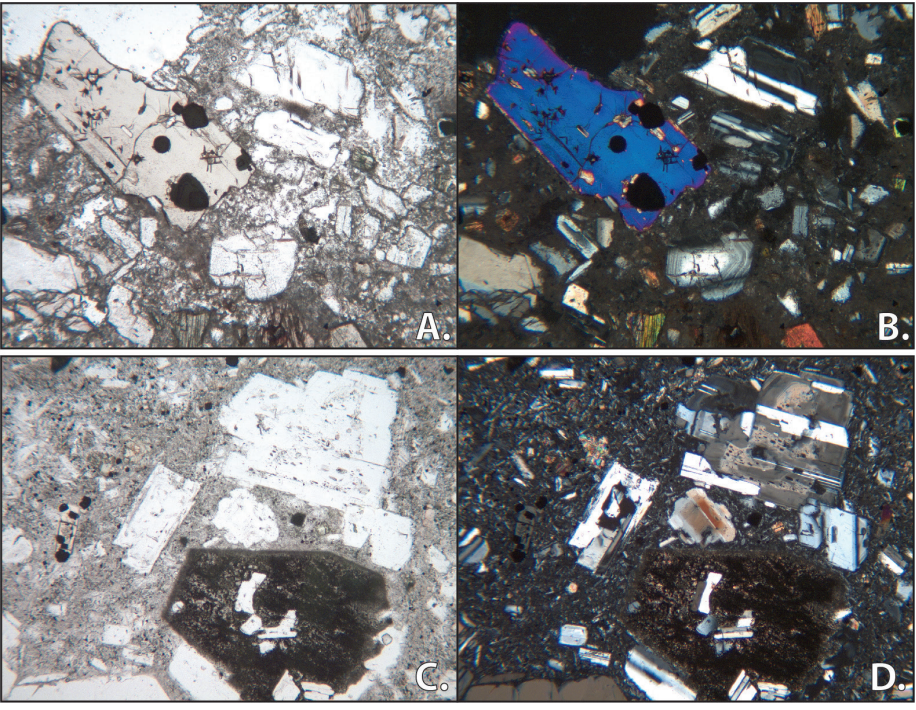

Figure 1. Roseau Ignimbrite sample RI-13 (A., PPL, 40x; B., XPL $40 x)$ contains plagioclase + clinopyroxene + orthopyroxene + ilmenite + magnetite grains with broken boundaries and a glass matrix, characteristic of pyroclastic deposits. Micotrin Dome sample MI-7 (C., PPL, 40x; D., XPL, 40x) contains a similar mineral assemblage as well as quartz and relict amphibole. MI-7 contains euhedral grains with a microcrystalline matrix.

\section{Whole Rock Geochemistry}

Major element chemistry reveals Micotrin Lava Dome deposits have lower $\mathrm{SiO}_{2}$ contents than Roseau Ignimbrite Group deposits (Fig. 2). Younger Roseau Ignimbrites (Casso Ignimbrite) have largely lower $\mathrm{SiO}_{2}$ contents than older Roseau Ignimbrites (Kings Hill Ignimbrite). In contrast trace elements, normalized to chondrite, illustrate the homogeneity of Wotten Waven deposits. Notably, younger deposits (Micotrin Lava Dome and Casso Ignimbrites being roughly the same age) have progressively lower LREE values, suggesting greater extent of partial melting of the mantle.

\section{Oxide and Plagioclase Compositions}

Most samples were analyzed using EDS at Union College (MI-1B, MI-7, RI-9, RI-10, RI-13, RI-15, KH-4). At UC Davis, EPMA analysis tested additional samples (MI-8, MI-9, RI-1A, RI-9) and validated Union College EDS analyses by reanalyzing samples (RI-9 and RI-13). Samples analyzed using both EDS and EPMA exhibit largely consistent oxide compositions with slightly elevated $\mathrm{TiO}_{2}$ levels in EDS data. This inflation of $\mathrm{TiO}_{2}$ under-predicts $\mathrm{fO}_{2}$ values using geothermometry analysis. Consequently, $\mathrm{fO}_{2}$ analysis was not the focus of this study. Samples containing chemically weathered oxides show dissolution of magnetite and ilmenite grains in EDS and EPMA as well as highly variable compositions. Samples exhibiting a weathering trend are distinct (Fig. 3) and are not used to calculate pre-eruptive temperatures and $\mathrm{fO}_{2}$. Ignimbrite deposits have more calcic plagioclase, with rims and cores ranging from $\mathrm{An}_{24}$ to $\mathrm{An}_{93}$, than subsequent Micotrin Dome deposits, with rims and cores ranging from $\mathrm{An}_{45}$ to $\mathrm{An}_{85}$ (Fig. 4).

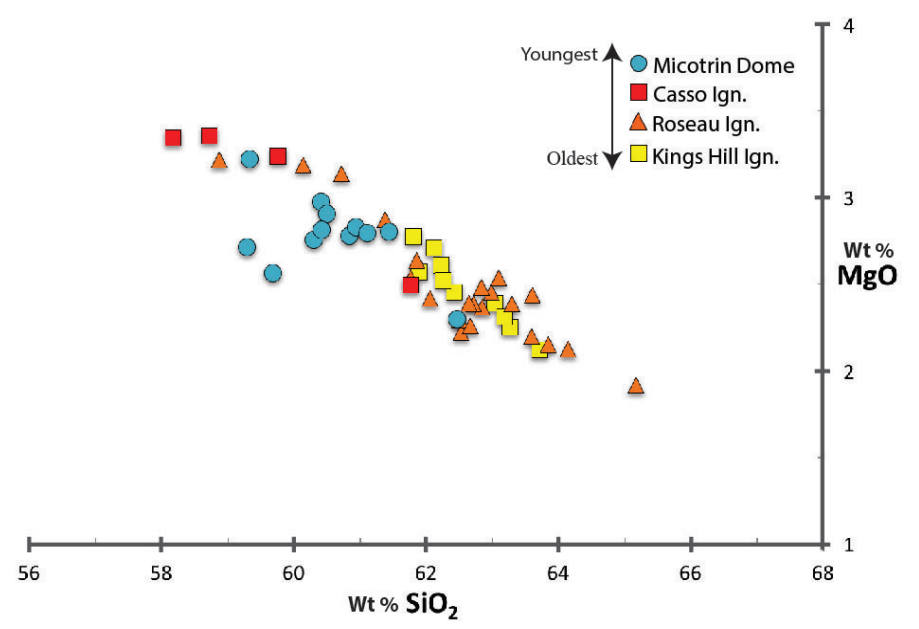

Figure 2. Major element geochemistry reveals younger deposits (Micotrin) have generally lower silica contents than older ignimbrite deposits (Kings Hill).

\section{Determination of Intensive Variables}

Fe-Ti oxide geothermometry using magnetite-ilmenite pairs reveals pre-eruptive conditions of the magma storage, including temperature and oxygen fugacity $\left(\mathrm{fO}_{2}\right)$ of the melt immediately before eruption. Oxide data was processed using the Hora et al. (2013) model, which applies the Ghiorso and Evans (2008) formulation of the Fe-Ti oxide thermometer and the Bacon and Hirschmann (1988) test for equilibrium. Roseau Ignimbrites demonstrate lower pre-eruptive temperatures $\left(\right.$ mean $\left.=831^{\circ} \mathrm{C}\right)$ and higher $\mathrm{fO}_{2}($ mean $=0.40$ $\triangle \mathrm{NNO}$ ) values than subsequent Micotrin Lava Dome deposits $\left(\right.$ mean $\left.=851^{\circ} \mathrm{C}, 0.30 \Delta \mathrm{NNO}\right)$ (Fig. 3).

Plagioclase hygrometry reveals melt water content at the time of peak plagioclase crystallization using the measured albite and anorthite components. Plagioclase 

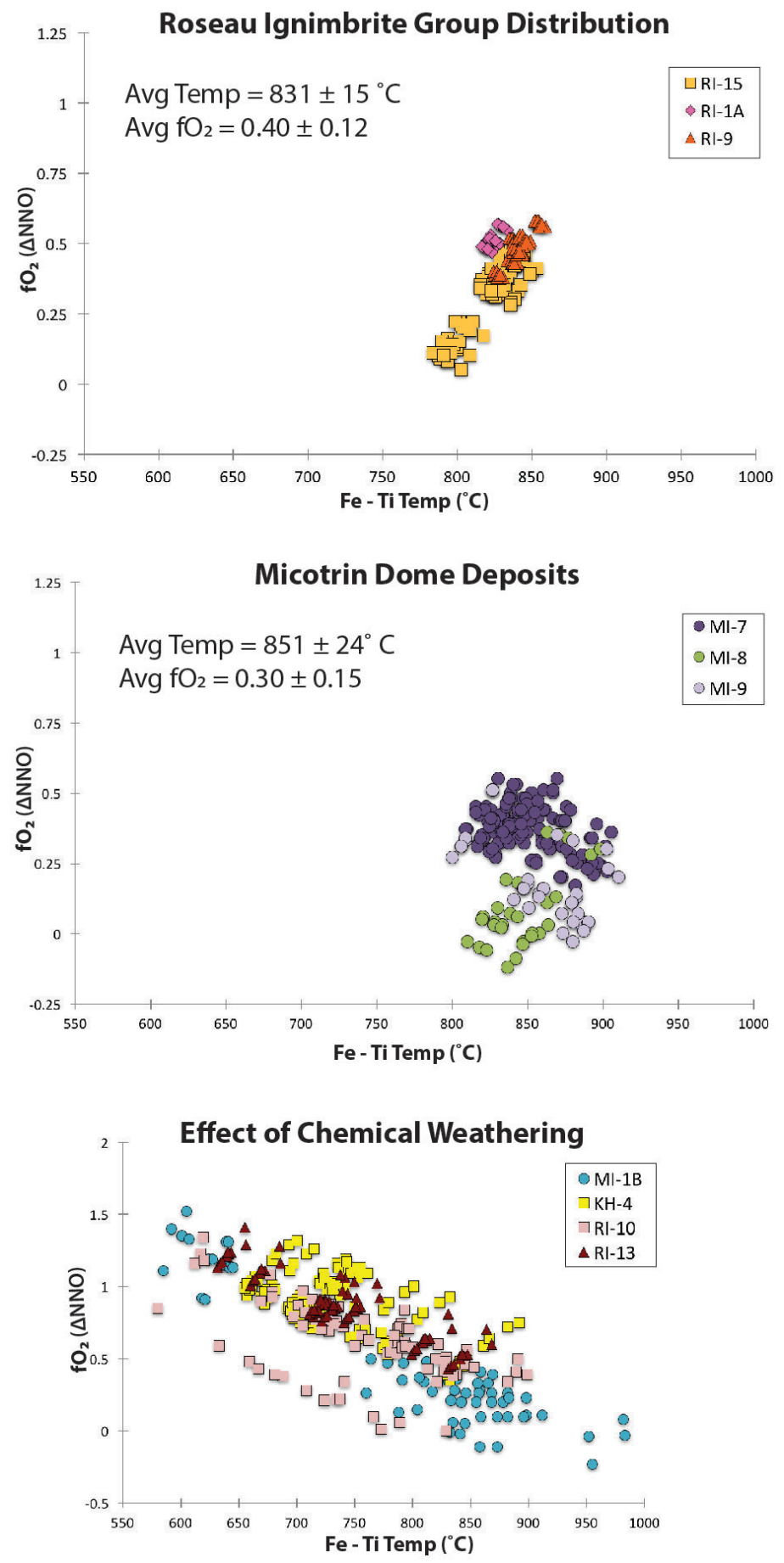

Figure 3. Oxide geothermometry reveals the pre-eruptive conditions of the magma system. Here we see pre-eruptive temperatures plotted against $\mathrm{fO}_{2}$. Each symbol represents an oxide pair within the sample. Samples showing a trend characteristic of chemical weathering have been separated, illustrating the limitations of fieldwork on a tropical island with a high precipitation rate. data was processed using the Waters and Lange (2015) plagioclase-liquid exchange hygrometer. This model incorporates independent Fe-Ti temperatures, plagioclase chemistry, and a proxy for melt composition, ideally interstitial glass. The microcrystalline matrix of Micotrin Dome deposits hosts little glass, so whole rock was used to supplement and better describe the water content in the changing conditions of the melt. Within each sample the most calcic plagioclase compositions were analyzed using whole rock composition to determine maximum water contents. The most sodic plagioclase compositions were analyzed using interstitial glass composition to determine the minimum water content. Accordingly, Roseau Ignimbrite deposits exhibit higher magmatic water contents (10.1-4.6 wt \% $\mathrm{H}_{2} \mathrm{O}$ ) than subsequent Micotrin Dome lavas (7.1-2.8 $\mathrm{wt} \% \mathrm{H}_{2} \mathrm{O}$ ).
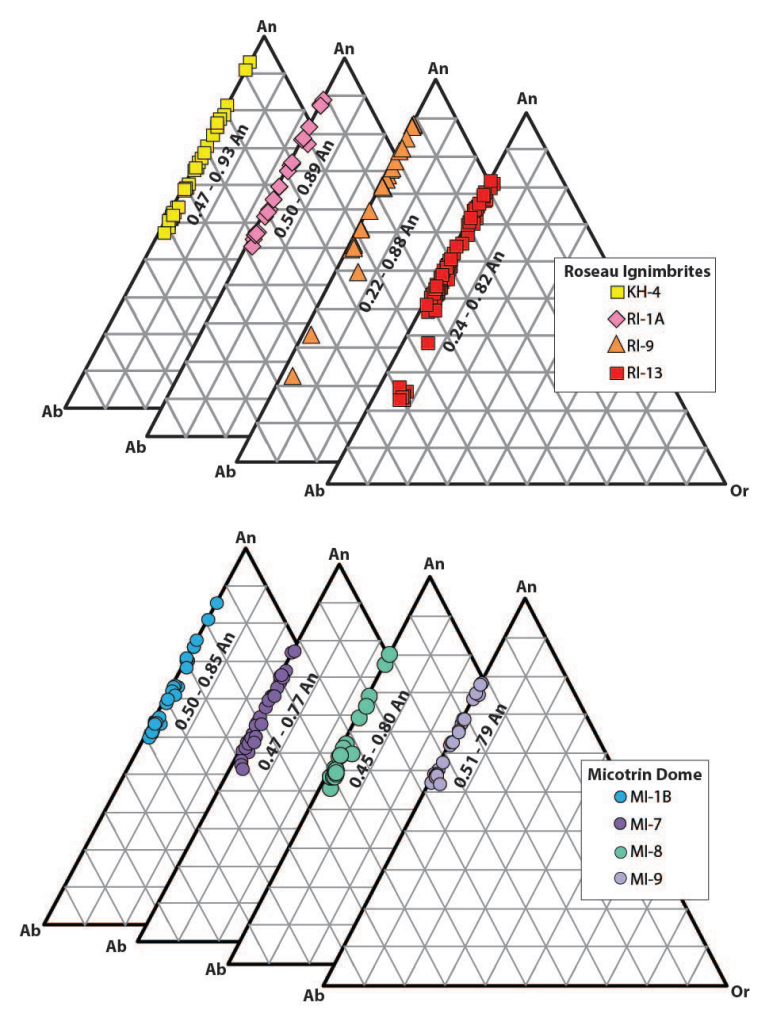

Figure 4. Plagioclase ternary diagrams show the spread of anorthite (An) and albite (Ab) components. Data include rims and cores.

\section{DISCUSSION}

This study establishes that the overall pattern of magmatism observed at Wotten Waven Caldera includes an initial, explosive interval of cold hydrous andesitic ignimbrites, followed by a second interval consisting 
of an effusive eruption of andesite with hotter preeruptive temperatures. Petrographic analysis reveals microcrystalline matrices of Micotrin Dome deposits, suggesting slow magmatic ascent. Whole rock geochemistry (Fig. 2) reveals Wotten Waven became less evolved over time, regardless of eruptive style. Oxide geothermometry reveals Micotrin Dome deposits to have higher pre-eruptive temperatures than previous Roseau Ignimbrite deposits. The decreasing silica content and increasing temperature found at Wotten Waven raises questions, as a homogenous, discrete magma body would be expected to become more siliceous, due to fractional crystallization, and cooler over time.

\section{Phase Diagram}

This phase diagram (Fig. 5) allows us to visualize the intensive variables (eruption temperature, pressure, water content) at Wotten Waven by plotting our natural samples against experimentally determined phase stability curves for a liquid with a composition similar to our samples (Holz et al., 2005). The water contents, calculated from the application of plagioclase-liquid hygrometry, are plotted as a function of the pre-eruptive temperature determined for each of our samples. Our samples have delineated a pattern consistent with crystallization coincident with magma ascent. Moreover, we find consistency between our samples and the phase equilibrium experiments and we conclude:

(1) The Ignimbrites are colder, and the water contents recorded by plagioclase crystallization are consistent with the position of the plagioclase-stability curve at higher pressures for lower temperatures. (2) Plagioclase crystallization ceases above the quartz-in curve in the ignimbrites, which may suggest that crystallization in the ignimbrite ceases at these conditions. This is consistent with the absence of quartz as a phenocryst phase in our ignimbrite samples.

\section{CONCLUSION}

Systematic variations in magmatic conditions between Roseau Ignimbrite and Micotrin Lava Dome deposits raise questions about the mechanism of magmatic evolution. Why does Wotten Waven Caldera experience a decrease in $\mathrm{SiO}_{2}$ content, an increase in pre-eruptive temperatures, and a decrease in melt water content during its evolution from explosive to effusive

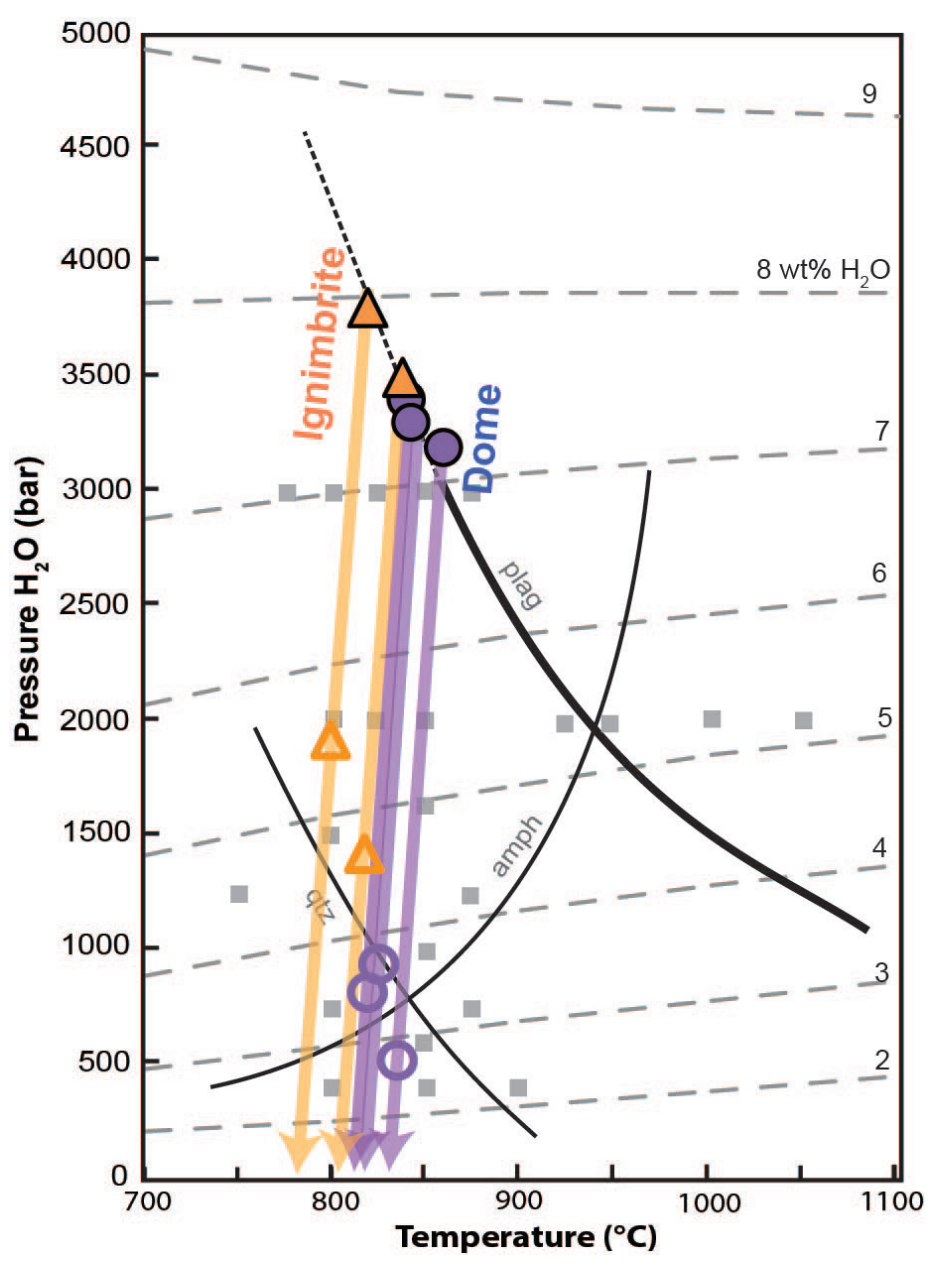

Figure 5. Phase diagram shows Wotten Waven deposits plotted against experimental data of a deposit with similar composition. Lines represent the evolution of the liquid as the system is evolving and decompressing in the time before eruption. Solid symbols represent maximum water content, indicating the onset of crystallization based on plagioclase hygrometry. Hollow symbols represent minimum water content, indicating the end of crystallization based on plagioclase hygrometry. Modified from Holz et al. (2005).

volcanism? Here, we consider three interpretations of the data. First, Micotrin Lava Dome may be sourced from a separate magmatic body than that of the Roseau Ignimbrites, and has taken advantage of the existing conduit system. The homogeneity of trace elements from both deposits, however, suggest they are sourced from the same magma system. Another interpretation is that Micotrin Lava Dome reflects the introduction of a hotter, more mafic melt to the system, adding heat and volatiles to the system while lowering the silica content. This idea of magmatic mafic recharge at Wotten Waven is supported by the presence of enclaves in the Micotrin Dome deposits, 
suggesting magma-mixing (Hickernell, 2018). A final alternative interpretation of the data is that Micotrin Lava Dome represents the last breath of a singular magma body that is stratified in both temperature and volatile content. Understanding the complexities of the magmatic evolution at Wotten Waven informs the hazards Dominica is exposed to and provides insight into the mechanism of volcanic expression at this magma system.

\section{ACKNOWLEDGEMENTS}

This material is based upon work supported by the Keck Geology Consortium and the National Science Foundation under Grant no. 1659322. I'd like to express my immense gratitude to Laura Waters, Holli Frey, and Kirsten Nicolaysen for their invaluable guidance and encouragement. Thank you to Matt Manon for his support and instruction. This research would not have been possible without the generous support of the Keck Geology Consortium, Whitman College, and Union College.

\section{REFERENCES}

Bacon, C.R. and Hirschmann, M.M. (1988) Mg/Mn partitioning as a test for equilibrium between coexisting Fe-Ti oxides. American Mineralogist 73: 57-61.

Boudon, G., Balcone-Boissard, H., Solaro, C., and Martel, C. (2017) Revised chronostratigraphy of recurrent ignimbrite eruptions in Dominica (Lesser Antilles Arc): Implications on the behavior of the magma plumbing system. Journal of Volcanology and Geothermal Research 343: 135-154.

Demange, J., Leborne, H., Traineau, H., and Westercamp, D. (1985) Histoire VolcanoStructurale De La Region Sud de la Dominique. Institute Mixte Recherches Geothermiques, 114p.

Frey, H.M. (2016) Dominica: The Sleeping Giant in the Caribbean. F\&M Scientist.

Ghiorso, M.S. and Evans, B.W. (2008)

Thermodynamics of rhombohedral oxide solid solutions and a revision of the Fe-Ti twooxide geothermometer and oxygen-barometer. American Journal of Science 308: 957-1039.
Hickernell, S. (2018) Magma Mixing: Magmatic Enclaves in Morne Micotrin, Domincia. 31st Keck Symposium Volume.

Holtz, F., Sato, H., Lewis, J., Behrens, H. and Nakada, S. (2005) Experimental petrology of the 1991-1995 Unzen Dacite, Japan. Part 1: Phase relations, phase composition, and pre-eruptive conditions. Journal of Petrology 46 (2): 319-337.

Howe, T.M., Lindsay, J.M., Shane, P., Schmitt, A.K., and Stockli, D.F. (2014) Re-evaluation of the Roseau Tuff eruptive sequence and other Ignimbrites in Dominica, Lesser Antilles. Journal of Quaternary Science 29(6): 531-546.

Hora, J.M., Kronz, A., Moller-McNett, S. and Worner, G. (2013) An Excel-based tool for evaluating and visualizing geothermobarometry data. Computers and Geoscience 56: 178-185.

Lindsay, J.M., Smith, A.L., Roobol, M.J., and Stasiuk, M.V. (2005) Dominica: Volcanic Hazards of the Lesser Antilles. Seismic Research Unit, The University of the West Indies, Trinidad and Tobago. 279 p.

Sigurdsson, H. (1972) Partly-welded pyroclastic flow deposits in Dominica, Lesser Antilles, Bulletin of Volcanology 36: 148-163.

Smith, A.L., Roobol, M.J., Mattioli, G.S., Fryxell, J.E., Daly, G.E., Fernandez, L.A. (2013) The Volcanic Geology of the Mid-Arc Island of Dominica, Lesser Antilles_-The Surface Expression of an Island-Arc Batholith. The Geological Society of America, Special Paper, V496, 249p.

Smith, R. and Bailey, R. (1968) Resurgent Cauldrons. Geological Society of America Memoir 116: 613-662.

Sun, S. and McDonough, W.F. (1989) Chemical and isotopic systematics of oceanic basalts: implications for mantle composition and processes. Geological Society, London, Special Publications 42: 313-345.

Wang, Y., Pan, H., Li, H. and Wang, C. (2007) Force field of the TMGL ionic liquid and the solubility and $\mathrm{SO} 2$ and $\mathrm{CO} 2$ in the TMGL from molecular dynamics simulation. Journal of Physical Chemistry 111(35): 10461-10467. 
Waters, L. and Lange, R. (2015) An updated calibration of the plagioclase-liquid hygrometerthermometer applicable to basalts through rhyolites. American Mineralogist 100(10): 2172-2184. 